\title{
OLIVE RESIDUES TO ENERGY CHAINS IN THE APULIA REGION PART I: BIOMASS POTENTIALS AND COSTS
}

\author{
Antonio Pantaleo, Maria Teresa Carone, Achille Pellerano
}

\section{Introduction}

Biomass from agro-forestry and agro-industrial residues can play a key role in achieving targets for fossil-fuel substitution. Olive tree pruning practices and olive oil extraction processes produce large amounts of residues. Olive growing involves $47 \%$ of Italian farms and covers $8 \%$ of the overall Utilized Agricultural Area. Apulia concentrates $22 \%$ of farms and $31 \%$ of total Italian area under olives [Istat 2000a] and is the main olive and olive oil producer in Italy.

The aim of this study is to review the olive-chain residues sector, estimate the energy potentials of the olive-oil chain residues in the Apulia region, namely pruning residues (PR) and crude olive husk $(\mathrm{COH})$, and assess the collection costs with different supply chain scenarios.

\section{Overview of the olive-chain residues}

\subsection{Olive tree pruning residues}

Olive tree pruning residues are a considerable source of biomass. They can be distinguished into wood (branches with a diameter of more than $40 \mathrm{~mm}$ ), shoots (branches with a diameter of less than $40 \mathrm{~mm}$ ) and leafy branches (small braches and leaves) [Amirante 2002; Spinelli 2000; Jimenez 2002]. Except for wood, which is still widely used as fuelwood, mostly in rural areas, shoots and leafy branches are very often not collected and recovered, because of their low value. For this reason, in this paper PR are represented only

Paper received 09.07.2008; accepted 13.01.2009

Corresponding author: Ing. ANTONio PANTAleo, a.pantaleo@agr. uniba.it. University of Bari, Department of Engineering and Management of the Agricultural, Livestock and Forest Systems Via Amendola 165/A 70125 BARI (Italy).

The contribution to the research set up and execution should be equally subdivided among the Authors. by shoots and leafy branches. On average, each olive tree produces $10-30 \mathrm{~kg} /$ year of $\mathrm{PR}$, depending on the structure and size of trees. Only in few cases pruning residues are used as animal feed. They are generally stacked and burnt on the field. Nowadays, with the implementation of alternative anti pathogen methods (which limit pathology diffusion caused by shoots and leafy branches left on the soil), pruning residues are sometimes chipped and ploughed in to provide plant nutrients. A ton of PR with a moisture content of $50 \%$ w.b. releases about $4 \mathrm{~kg}$ of $\mathrm{N}, 0,5 \mathrm{~kg}$ of $\mathrm{P}, 0,5 \mathrm{~kg}$ of $\mathrm{K}$, $5 \mathrm{~kg}$ of $\mathrm{Ca}$ and $1 \mathrm{~kg}$ of $\mathrm{Mg}$. In most cases, however, the cost of this operation is not balanced by the increment in plant yield [Amirante 2002]. As a consequence, it should be more efficient to recover these residues and use them for energy purposes. An appropriate mechanization and rationalization of pruning residues collection, package and transport operations could enhance their use for energy purposes.

The most relevant properties of PR, in view of their energy use, are Lower Heating Value (LHV), moisture content, ash content and size. Moisture content and size depend on the collection and treatment techniques, while ash content and LHV depend on physical and chemical characteristics. In particular moisture content depends on plant's age, collection time, collection and storage conditions, both on field and at dedicated facilities. On average, leafy branches have a moisture content at collection time of $50 \%$ d.b., a C-N ratio of $33 \%$ d.b. [Amirante 2002].

\subsection{Olive husk and olive mill wastewater}

Another relevant source of biomass, suitable for energy purposes, is the olive oil extraction process. It is a widely implemented agro-industrial activity which has a huge relevance for the economy of Mediterranean Countries, that are responsible for $99 \%$ of the annual worldwide production of olive oil (about 2.7 million tons/year) [ISMEA 2003]. The main byproducts of the olive oil mills are the olive mill wastewater (OMW) and the crude olive husk $(\mathrm{COH})$ (or crude olive cake). Every year Mediterranean Countries produce about 30 million $\mathrm{m}^{3}$ of OMW and 20 
million tons of $\mathrm{COH}$ [Boubaker 2007]. Because of the production of highly polluted wastewater and/or solid residue, the extraction process has a relevant environmental impact [Rodriguez 2007].

Olive oil mills can be of the traditional oil-press batch type operation or continuous processes using either two- or three-phase decanter centrifugation systems. The amount of waste produced depends directly on the extraction system, as well as on such other factors as the type of olive and land, pesticide and fertilizer use, etc. [Caputo 2003]. Traditional pressing is a relatively obsolete technology but it is still in use for some olive oil producers; it generates olive oil (20\% of olives), $\mathrm{COH}$ ( $40 \%$ of olives) and OMW (40\% of olives). The most common olive oil extraction technologies are three- and two-phase centrifugation systems. The three-phase technique produces olive oil (20\% of input olives), $\mathrm{COH}$ with a moisture content of $46-54 \%$ w.b. (50\% of olives) [Alfano 2007; Castellano 2005], and a huge amount of OMW (120\% of olives) [Alburquerque 2004], since water is added in different steps to facilitate oil extraction. This led to the introduction, in the early nineties, of a two-phase "ecological" extraction system that produces olive oil (20\% of olives) and olive sludge (OS) with high moisture content ( $80 \%$ olives), which is husk soaked with OMW [Alburquerque 2004], [Gelegenis 2007]. This process still presents the problem of the OS discharge, because of the high moisture content (60-80\% w.b) and phenols content. In particular, the high moisture content makes it unprofitable to process OS for pomace oil extraction, which is, on the contrary, the most widespread treatment system for $\mathrm{COH}$. Despite of this, as the process uses no water during the oil extraction, there is a dramatic reduction in OMW production, thus minimizing the discharge issues [Alburquerque 2004; Gurbuz 2004].

In the Apulia region scenario, the three-phase centrifugation system is often coupled to a preliminary two-phase step, as the OS, after de-stoning, is further processed in order to extract additional oil, by adding water. This process also allows producing olive stones (the so-called pits) which are an high valuable biofuel. Olive stones are commonly used in dedicated boilers on site to serve the heat demand of the milling process, but also sold as a substitute to fossil fuels for energy production (mainly heat for greenhouses). Moreover, the $\mathrm{COH}$ from three-phase systems could also be further pressed to extract water and obtain a crude husk with lower moisture content, which could be sold to pomace-extraction plants at an higher price (the maximum moisture content of $\mathrm{COH}$ for pomaceoil extraction is $50-55 \%$ w.b.).

\subsection{Uses of olive mills by-products}

At present, most of $\mathrm{COH}$ is processed in pomaceextraction plants in order to extract the low percentage of contained residual oil (pomace oil) and obtain, as a by-product, the exhausted olive husk (EOH), which has a low moisture content $(8-12 \%$ w.b.) and is widely used as biofuel for heat and power production. However, the declining market demand for pomace oil, which is a low-quality product, the diffusion of two-phase extraction systems that have OS as byproduct and the $\mathrm{COH}$ storage and transport issues are causing a reduction in the number of pomace-extraction plants in operation, thus raising the problem of COH disposal [Caputo 2003].

In some cases, $\mathrm{COH}$ is discharged on the soil as an organic fertilizer; however, the fatty acid, phenol and tannin content (highly phytotoxic compounds) of $\mathrm{COH}$ is the main obstacle to this technique [Alfano 2007] due to the formation of an impermeable barrier on the soil surface that would interfere with gas exchange and water infiltration [Quaratino 2007]. Over the past few decades olive husks have also been used as a potential raw material in bioprocesses, as they provide an excellent substratum for the growth of some micro-organisms, and in composting processes.

Moreover, during the last decade, there has been a marked tendency towards the energy valorisation of $\mathrm{COH}$, after drying processes [Celma 2008; Alkhamis 1999].

As to OMWs, they have different characteristics depending on olive harvesting period, olive variety and maturity, soil conditions and oil extraction method [Ammar 2005; Borja 2006]. OMW average composition is water $(60-70 \%)$, lignin $(13-15 \%)$, cellulose and hemicellulose $(18-20 \%)$, residual olive oil $(3 \%)$, volatile fatty acids $(1 \%)$, polyphenols $(0,2 \%)$, polyalcohols $(0,2 \%)$, proteins $(1,5 \%)$ and other pigments $(0,5 \%)$ [Borja 2006]. Aromatic compounds (polyphenols) are the main responsible for OMW phytotoxic and antimicrobial effects [Quaratino 2007]. Typical range for OMW chemical oxygen demand (COD) is $50-150 \mathrm{~kg} / \mathrm{m}^{3}$, with extreme values up to $200 \mathrm{~kg} / \mathrm{m}^{3}$; biological oxygen demand (BOD) has an average value of $45 \mathrm{~kg} / \mathrm{m}^{3}$ of OMW [Gelegenis 2007].

The classical discharge of OMWs is on field as organic fertilizers, but there are some major negative aspects related to this discharge practice, namely: (i) during autumn and winter, a period of high rainfall, the application of OMW can lead to detrimental stagnation and the formation of anaerobic microsites; (ii) the percolation of the wastewaters into superficial aquifers can cause pollution [Filidei 2003].

The environmental concerns arising from the discharge of OMW are the major drivers in the investigation of new technologies for a sustainable OMW management [Jarboui 2008]. In recent years different disposal methods of OMW have been proposed: flocculation-clarification, ultrafiltration/reverse osmosis, thermal concentration and evaporation, incineration and combustion [Amirante 1992; Alfano 2007] evaporation in storage ponds, microbiological treatments for the production of biopolymers, aerobic treatments with micro-organisms, composting, anaerobic digestion for the production of biogas, photochemical 
degradation of phenols, electrocoagulation, extraction of valuable products [Rodriguez 2007]. These methods are generally very expensive and/or unable to completely solve the problem because of the need to dispose of a residual sludge from the process [Alfano 2007]. Anaerobic digestion treatments [Filidei 2003; Raposo 2004; Gelegenis 2007] have been carried out successfully on OMW, resulting in biogas production and much less waste sludge in comparison to other techniques, even if the high costs are the main counterpart, in particular for small scale olive mills.

The last by-product of the olive oil industry, olive stone (pit), can be recovered by filtration of $\mathrm{COH}$ from the olive oil extraction. Olive stone is a lignocellulosic material, with high commercial value as fuel, because of its low $\mathrm{N}$ and $\mathrm{S}$ content, which minimizes the $\mathrm{NO}_{x}$ and $\mathrm{SO}_{2}$ emissions from combustion [Gonzalez 2004]. Its calorific value is about $18,8 \mathrm{MJ} / \mathrm{kg}$ and it is usually used as a fuel in greenhouses, ceramic and lime production plants, bakeries, power and heating plants as well as in the olive mills and seed oil mills themselves [Vlyssides 2008]. Despite of the environmental benefits of using this biomass as a fuel, some problems remain such as air pollution (CO and particulates such as soot and ash produced by combustion) [Rodriguez 2007].

\section{Methodology}

\subsection{General methodology overview}

This work is divided into two main parts. The first one regards the assessment of the olive oil chain residues potentials for energy purposes in Apulia region and their spatial location and costs. For this purpose, statistical data regarding both olive and oil production are analysed, applying a specific methodology to quantify the available biomass. Moreover, experimental PR harvesting and treatment tests are carried out in order to calculate their supply costs. As regards olive oil extraction process by-products, the local markets of $\mathrm{COH}, \mathrm{EOH}$ and olive stones are analysed by means of interviews to the main operators, in order to evaluate the prices and to draw a picture of both the present uses of these materials and the trends of the sector.

In the second part, a techno-economic assessment of the most promising options for energy conversion of these residues is proposed. After reviewing the technological options for the energy conversion of the selected biomass typologies, the specific Italian and regional legislative framework, the logistic issues and regional transport infrastructure the regional most promising three case-studies are selected and discussed.

\subsection{Biomass supply assessment}

3.2.1 Biomass potentials

The methodology proposed by the Italian Agricul- tural Engineering Association (AIIA) and ENEA [AIGR 1994] is applied to estimate the potential quantity ( $\mathrm{t}$ d.m./year) and the density $\left(\mathrm{t} \mathrm{d} . \mathrm{m} . / \mathrm{km}^{2}\right)$ of the olive tree PR on the territory. This methodology has been widely implemented to assess agricultural residues potentials, also including specific applications to the Apulia region [Regione Puglia 2003].

In order to quantify PR, the following data are used:

- relationship main by-product $1 /$ product $\left(\mathrm{S}_{1} / \mathrm{P}\right)$;

- harvesting frequency, moisture content and potential availability of by-products;

- statistic data on land use.

The relationship $S_{1} / P$ is a crucial factor, since it varies with cultivars, cultivation techniques, soil conditions, harvesting methods, phytopathological aspects, etc. For the Apulia region, the correlation between the yield of olives and PR can be expressed by the following equations [ANPA 2001]:

Provinces of Foggia and Bari:

$\mathrm{PR}(\mathrm{t} / \mathrm{ha})=0,566 \mathrm{Y}+1,496$

Provinces of Taranto, Brindisi, Lecce:

$\mathrm{PR}(\mathrm{t} / \mathrm{ha})=0,305 \mathrm{Y}+1,401$

where:

$\mathrm{Y}=$ olive production yield $\left(\mathrm{t} / \mathrm{ha}^{*} \mathrm{y}\right)$.

The quantity of PR potentially available for energy purposes is affected by some operating factors (harvesting and conditioning techniques, size and slope of the field, permanence time on field, climatic conditions during the recovery). For this purpose, an availability coefficient $A_{P}$ is introduced. The amount of available $\mathrm{PR}$ per ha $\left(\mathrm{D}_{\mathrm{PR}}\right)$ can be expressed as follows:

$D_{p s}=P\left(\frac{S_{1}}{P}\right)\left(\frac{1-U S_{1} / 100}{F S_{1}}\right)\left(\frac{A_{p}}{100}\right) \quad[\mathrm{t}$ d.m./ha*year $]$

where:

$\mathrm{P}=$ main product yield (olives) ( $\mathrm{t} / \mathrm{ha}^{*}$ year);

$\mathrm{S}_{1} / \mathrm{P}=$ main by-product/total production yield ratio;

$\mathrm{US}_{1}=$ average moisture content on wet basis of the main by-product (\%);

$\mathrm{FS}_{1}=$ pruning frequency (years);

$\mathrm{A}_{\mathrm{p}}=$ potential availability of the main by-product $(\%)$.

\footnotetext{
1 The AIIA-ENEA methodology distinguishes two types of agricultural residues for woody crops: the main by-product $S_{1}$ (pruning residues) and the secondary by-product $S_{2}$ (rooting out wood). $S_{2}$ is available only when trees are at the end of their life cycle, so with a multiannual frequency. In this work it is not considered for olive trees because most of them are more than 60 years old. Whatever, $\mathrm{S}_{2}$ for olive trees represents a low quantity that Loi [1994] assesses to be equal to $10 \mathrm{kt} \mathrm{d.m./year} \mathrm{in} \mathrm{Apulia,} \mathrm{and} \mathrm{which} \mathrm{is} \mathrm{used} \mathrm{to} \mathrm{produce} \mathrm{high} \mathrm{quality} \mathrm{fi-}$ rewood, mainly for rural areas and bakery heating demand.
} 
The overall quantity of PR available in each municipality is calculated as the product of $\mathrm{D}_{\mathrm{PR}}$ and land covered by olive trees (ha) at municipal level. For this purpose, data from ISTAT [Istat 2000a] are used in order to estimate the olive plantations surface in each Community. As regards the main product yield $\mathrm{P}$ in eqn (3), for each municipality the value of the related Province is considered [Istat 2000b].

The relative energy potential of the biomass can be calculated by the following relation:

$V=L H V \cdot\left(1-\frac{U}{100}\right)-C_{v} \frac{U}{100} \quad$ [TEP/t d.m.]

where:

$\mathrm{V}=$ energy content (TEP/t d.m.);

$\mathrm{LHV}=$ lower heating value (TEP/t d.m.);

$\mathrm{C}_{\mathrm{v}}=$ latent heat of evaporation of water (TEP/t d.m.);

$\mathrm{U}=$ moisture content on wet basis of the material $(\%)$.

In the case of PR, a natural drying of the biomass up to $15 \%$ w.b. is considered (both on field or at the storage plant), so that the moisture content reported in eqn (4) is referred to the dried biomass.

The energy potentials of $\mathrm{COH}$ are estimated by means of statistic data about annual amounts of pressed olives, oil and $\mathrm{COH}$ produced and typology of olive oil extraction mills. The production data from Assessorato all'Agricoltura of Apulia region in the period 2002-2005 are considered. These data are also compared with $\mathrm{COH}$ and $\mathrm{EOH}$ production rates from local olive oil producers associations (ASSITOL) and pomace-oil extraction mills operating in Apulia. Moreover, the extraction process (traditional vs twoor three-phase systems) is also considered, since it affects the moisture content and LHV of the $\mathrm{COH}$ and, in turn, its energy content, which is estimated by the (4). The EOH potentials are estimated from $\mathrm{COH}$ potentials considering an average pomace oil content in $\mathrm{COH}$ of $5 \%$ in weight and a moisture content of $\mathrm{EOH}$ of $12,5 \%$ w.b.

$Q_{\text {me }}=Q_{\text {Can }}\left(1-\frac{U_{\text {Can }}-U_{\text {Dar }}}{100}\right)-0,05 \cdot Q_{\text {ont }} \quad[\mathrm{t} /$ year $]$

where:

$\mathrm{Q}_{\mathrm{EOH}}=$ availability of $\mathrm{EOH}$ (t/year);

$\mathrm{Q}_{\mathrm{COH}}=$ availability of $\mathrm{COH}$ ( $\mathrm{t} /$ year);

$\mathrm{U}_{\mathrm{COH}}=$ moisture content on wet basis of $\mathrm{COH}(\%)$.

$\mathrm{U}_{\mathrm{EOH}}=$ moisture content on wet basis of $\mathrm{EOH}(\%)$.

The relative energy potential of the $\mathrm{COH}$ and $\mathrm{EOH}$ is calculated according to eqn (4), being $U$ the moisture content of the biomass (before drying in the case of $\mathrm{COH})$. The rationale behind this assumption is simply that it is not possible to undertake a natural drying of $\mathrm{COH}$, so that the energy content of the biomass should take in account the energy consumed for drying. On the other hand, EOH presents a low moisture content $(12,5 \%$ w.b.) so that it is already a dried biofuel.

\subsubsection{Biomass costs}

In order to assess the PR supply costs, in this work the following harvesting techniques are examined through experimental field tests:

- harvesting and rotobaling on field and chipping at the conversion plant (Scenario 1);

- harvesting and chipping on field (Scenario 2).

The PR supply cost is calculated according to Ceestat [1988], and in particular the variable and fixed operational costs are taken into account. Olive tree pruning costs are not included in the costs assessment, since this practice is carried out independently from the biomass recovery for energy purposes.

In order to investigate actual uses, traded quantity and prices of olive husk, an analysis of the pomace oil extraction sector in Apulia is carried out. The rationale behind this analysis is that most of the $\mathrm{COH}$ produced by oil extraction mills in Apulia is used for pomace oil production by chemical extraction in a few dedicated plants. The assessment is based on interviews to pomace extraction plant operators, in order to collect data about traded amounts of olive husks and market prices of $\mathrm{COH}$ and $\mathrm{EOH}$, location and techno-economic characteristics of pomace-extraction plants in the region and, in turn, to address the main issues for the energy conversion of olive husk.

\section{Application}

\subsection{Biomass supply assessment}

\subsubsection{Biomass potentials}

Table 1 reports the coefficients used for the PR potentials assessment, as resulting from eqn (3). The potential availability $A_{P}$ is estimated according to literature data [Arrivo 1983; Regione Puglia 2003; ANPA 2001; Baldini 1982; Balsari 2000] and personal communications with operators. In order to calculate the energy content of the biomass by eqn (4), a mean PR moisture content $U$ equal to $15 \%$ w.b. (corresponding to the moisture content of PR after natural drying) and a lower heating value (LHV) of $18 \mathrm{MJ} / \mathrm{kg} \mathrm{d.m}$. are assumed.

The total energy content of PR for each municipality is calculated as the product of the energy content of the biomass from eqn (4) $(0,348 \mathrm{TEP} / \mathrm{t})$ and the municipal availability of PR (t/y).

The potential availability of $\mathrm{COH}$ is assessed using

\begin{tabular}{|l|c|c|c|c|c|}
\hline & FOGGIA & BARI & TARANTO & BRINDISI & LECCE \\
\hline $\mathrm{S} 1 / \mathrm{P}$ & $\begin{array}{c}\text { Eqn } \\
(1)\end{array}$ & $\begin{array}{c}\text { Eqn } \\
(1)\end{array}$ & $\begin{array}{c}\text { Eqn } \\
(2)\end{array}$ & $\begin{array}{c}\text { Eqn } \\
(2)\end{array}$ & $\begin{array}{c}\text { Eqn } \\
(2)\end{array}$ \\
\hline $\mathrm{FS}_{1}$ (years) & 3 & 3 & 3 & 4 & 4 \\
\hline $\mathrm{US}_{1}(\%)$ & 30 & 30 & 30 & 30 & 30 \\
\hline $\mathrm{A}_{\mathrm{P}}(\%)$ & 80 & 80 & 80 & 80 & 80 \\
\hline
\end{tabular}

TABLE 1 - Coefficients used for the PR potential assessment [Regione Puglia 2003; ANPA 2001]. 
data from the Assessorato all'Agricoltura of the Apulia region. In particular, the data of the period 20022005 and referred to each municipality are averaged. In Apulia, during these seasons, about $2 * 10^{6}$ tons of olives were pressed, with oil and $\mathrm{COH}$ yields of around $342.000 \mathrm{t}(17,1 \%)$ and $915.000 \mathrm{t}(45,7 \%)$, respectively, as reported in Table 2 . The specific $\mathrm{COH}$ production per olive oil mill resulted on average of $705 \mathrm{t} /$ year, with values variable between 15 (San Marco la Catola - FG) and 6.330 t/year (Presicce - LE). The amount of EOH (moisture 12,5\%) is calculated by eqn. (5).

As previously discussed, $\mathrm{COH}$ moisture content varies as a function of the oil extraction process. For this reason, in order to estimate the $\mathrm{COH}$ energy potential, a distinction between $\mathrm{COH}$ produced by traditional oil mills ( $25 \%$ w.b. moisture content) and $\mathrm{COH}$ produced by three-phase continuous processes $(55 \%$ w.b. moisture content) is considered. The average distribution of the extraction processes implemented by oil mills across the different areas of the Apulia region in the period 2002-2005 is reported in Table 3. The LHV of $\mathrm{COH}$ is assumed to be $18,8 \mathrm{MJ} / \mathrm{kg} \mathrm{d.b}$.

\begin{tabular}{|c|c|c|c|c|c|c|}
\hline & FG & BA & TA & BR & LE & TOTAL \\
\hline $\begin{array}{l}\text { Pressed } \\
\text { olives } \\
\text { (t/year) }\end{array}$ & 152.522 & 600.806 & 118.714 & 478.130 & 651.825 & 2.001 .997 \\
\hline Oil (t/year) & 27.286 & 109.908 & 18.618 & 71.933 & 114.481 & 342.225 \\
\hline $\begin{array}{l}\mathrm{COH} \\
\text { (t/year) }\end{array}$ & 67.219 & 268.252 & 52.849 & 226.334 & 299.699 & 914.354 \\
\hline $\begin{array}{l}\text { Oil yield (\% } \\
\text { of olive) }\end{array}$ & 17,9 & 18,3 & 15,7 & 15,0 & 17,6 & 17,1 \\
\hline $\begin{array}{l}\text { COH yield } \\
\text { (\% of olive) }\end{array}$ & 44,1 & 44,6 & 44,5 & 47,3 & 46,0 & 45,7 \\
\hline $\begin{array}{l}\text { Olive oil } \\
\text { extraction } \\
\text { mills }\end{array}$ & 199 & $375(*)$ & 120 & 177 & 426 & 1.297 \\
\hline $\begin{array}{l}\text { Average } \\
\mathrm{COH} \text { plant } \\
\text { prod. (t) }\end{array}$ & 338 & 715 & 440 & 1.279 & 703 & 705 \\
\hline
\end{tabular}

TABLE 2 - Average production rates and number of oliveoil extraction mills during the period 2002-2005 in Apulia (Assessorato all'Agricoltura of the Apulia Region).

\begin{tabular}{|l|c|c|}
\hline AREA & $\begin{array}{c}\text { Three-phase continuous } \\
\text { systems }\end{array}$ & Traditional systems \\
\hline Foggia and Bari & $84 \%$ & $16 \%$ \\
\hline $\begin{array}{l}\text { Taranto, Brindisi and } \\
\text { Lecce }\end{array}$ & $93 \%$ & $7 \%$ \\
\hline
\end{tabular}

TABLE 3 - Extraction processes adopted by oil mills, period 2002-2005, (\% of produced COH) [Unaprol 2005].
The EOH energy content is calculated considering an average moisture content of $12,5 \%$ w.b. and a LHV of $18 \mathrm{MJ} / \mathrm{kg}$ d.b. According to eqn (4), the energy content results as follows:

- 0,369 TEP/t for the EOH $(\mathrm{U}=12,5 \%$ w.b. $)$;

- 0,308 TEP/t for $\mathrm{COH}$ from traditional systems (U $=25 \%$ w.b.);

- 0,161 TEP/t for $\mathrm{COH}$ from three-phase continuous systems ( $\mathrm{U}=55 \%$ w.b.).

The total energy content of $\mathrm{COH}$ and $\mathrm{EOH}$ for each municipality is calculated as the product of the biomass energy content from eqn (4) and the municipal availability of $\mathrm{COH}$ and $\mathrm{EOH}(\mathrm{t} / \mathrm{y})$ as from statistical data.

\subsubsection{Biomass costs}

The assessment of the PR supply costs is carried out assuming two possible scenarios: rotobaling and on site chipping.

\section{A) Rotobaling (Scenario 1)}

In this case, residues are windrowed and collected with hay balers in order to obtain cylindrical bales of about 1,50 $\mathrm{m}$ diameter and 1,20 $\mathrm{m}$ height. In the present research, an experimental test of PR rotobaling in a secular olive grove (50 trees/ha), less than $5 \%$ ground slope, near Ostuni (BR) is carried out. After pruning, the greater sized wood, used as firewood, is selected and separated, while brushwood is dried on the field for about 1 week and windrowed with a swath rake and a tractor. Successively, the residues are processed by means of a Feraboli FF50 rotobaling machine coupled to a $50 \mathrm{~kW}$ tractor. The bales are then stored on field and transported to the energy conversion plant. In order to quantify the transport costs, an average distance of $50 \mathrm{~km}$ between biomass production and conversion places is assumed. In order to carry out the biomass supply cost analysis, the costs of the swath rake, the rotobaler, the working time and of the labour (3 persons) are kept into account.

B) Picking-chipping-loading machine (Scenario 2)

In this case, pruning residues are windrowed and chipped with a picking-chipping-loading machine, which picks up residues, chips (medium particle size of $3 \mathrm{~cm}$ ) and loads them in a self mounted well deck. In this case, the PR are stored on field for 2 weeks in order to allow a proper biomass drying up to about $30 \%$ moisture content w.b., which is a pre-requisite for a proper chipping. Field experiments are carried out in Fasano (BR) on the same typology of olive trees considered in the previous case. Experimental tests are based on the use of a $60 \mathrm{~kW}$ BERTI Picker 140 machine.

\section{C) Olive husk market assessment}

The regional olive husks market is assessed by means of structured interviews to pomace-oil extraction plants operators in Apulia. For each plant, the following data are collected:

- plant characteristics, i.e. plant size (amounts of processed $\mathrm{COH}$ and produced $\mathrm{EOH}$ and husk oil), olive husk storage capacity and average biomass 
storage time, working season length, $\mathrm{COH}$ drying plant characteristics;

- $\mathrm{COH}$ and $\mathrm{EOH}$ average moisture content;

- percentage of EOH used on site to serve the plant thermal energy demand and remaining amount of $\mathrm{EOH}$ available for energy conversion processes;

- $\mathrm{COH}, \mathrm{EOH}$, husk oil and olive stone selling and purchase prices.

\section{Results and discussion}

\subsection{Biomass supply assessment}

\subsubsection{Biomass potential}

The olive tree PR potentials are summarized in Table 4. Most of the PR potentials are located in the Provinces of Bari (over $61.000 \mathrm{t}$ d.m./year), Lecce (about $31.000 \mathrm{t}$ d.m./year) and Foggia (30.000 t d.m./year). The density of the resource has the highest values in the provinces of Bari and Lecce, with 11,9 and $11,3 \mathrm{t} / \mathrm{km}^{2}$ of dry matter, respectively, followed by Brindisi $\left(10 \mathrm{t} / \mathrm{km}^{2}\right)$, Taranto $\left(5 \mathrm{t} / \mathrm{km}^{2}\right)$ and Foggia $\left(4,2 \mathrm{t} / \mathrm{km}^{2}\right)$.

The analysis shows that the olive trees of the Apulia region produce a remarkable amount of PR (about

\begin{tabular}{|l|c|c|c|c|c|c|}
\hline PARAMETER & FG & BA & TA & BR & LE & TOT. \\
\hline Surface $\left(\mathrm{km}^{2}\right)$ & 7.192 & 5.138 & 2.429 & 1.839 & 2.759 & 19.358 \\
\hline $\begin{array}{l}\text { Availability } \\
\text { (t d.m./year) }\end{array}$ & 30.313 & 61.322 & 12.792 & 18.206 & 31.263 & 153.897 \\
\hline $\begin{array}{l}\text { Density } \\
\left.\text { (t d.m./km }{ }^{2}\right)\end{array}$ & 4,21 & 11,93 & 5,27 & 9,90 & 11,33 & 7,95 \\
\hline $\begin{array}{l}\text { Availability } \\
\text { U=15\% (t/year) }\end{array}$ & 34.860 & 70.520 & 14.710 & 20.937 & 35.953 & 176.981 \\
\hline $\begin{array}{l}\text { Energy potential } \\
\text { (TEP/year) }\end{array}$ & 12.131 & 24.541 & 5.119 & 7.286 & 12.511 & 61.589 \\
\hline
\end{tabular}

TABLE 4 - PR potentials in the Apulia region.
$177.000 \mathrm{t} /$ year with moisture content of $15 \%$ w.b.) with a total energy content of over 61.000 TEP. Despite of this, the proposed assessment does not report the percentage of this resource which is already used for energy purposes. According to interviews and personal communications with operators in the olive sector, this percentage should be in the range of $5-20 \%$, on the basis of the different areas of the region and the particular typology of trees and local demand of PR as biofuels.

The $\mathrm{COH}$ and $\mathrm{EOH}$ potentials are reported in Table 5. The availability of $\mathrm{COH}$ and $\mathrm{EOH}$ results of about 915.000 t/year (152.000 TEP/year) and 503.000 t/year (185.600 TEP/year), respectively. The results show that Lecce is the province with the largest energy potentials from EOH (nearly $61.000 \mathrm{TEP} /$ year), while Bari and Brindisi present, respectively, potentials of 54.500 and 45.900 TEP/year.

The results of the potentials assessment are referred to an average of 3 years (2002-05), while the amount of annually pressed olives and, therefore, of produced $\mathrm{COH}$ is affected by variations over the years, which should be taken into account in a more accurate investigation.

$\mathrm{EOH}$ potentials are estimated by eqn (5) and using as input data the $\mathrm{COH}$ potentials, so that they represent the quantity of biomass which could be available if all the $\mathrm{COH}$ would be used in pomace-oil extraction plants to produce $\mathrm{EOH}$ as by-product. However, this is not the case, as appears from the results of the interviews reported in the following section. The total energy potential of $\mathrm{EOH}$ is higher than $\mathrm{COH}$ because of its lower moisture content. The $\mathrm{EOH}$ is commonly produced by pomace-oil extraction plants in a quite energy intensive process, where $30 \%$ of the $\mathrm{EOH}$ is on average consumed on site to produce the thermal energy needed to dry the $\mathrm{COH}$ and operate the pomace-oil extraction plant (so that this amount of EOH for autoconsumption should be taken into account when assessing the overall EOH availability as biofuel).

\begin{tabular}{|c|c|c|c|c|c|c|}
\hline CHARACTERISTICS & FOGGIA & BARI & TARANTO & BRINDISI & LECCE & TOTAL \\
\hline $\begin{array}{l}\mathrm{COH} \text { traditional process ( } 25 \% \text { moisture w.b.) } \\
\text { (t/year) }\end{array}$ & 10.755 & 42.920 & 3.699 & 15.843 & 20.979 & 94.197 \\
\hline $\begin{array}{l}\text { Energy potential COH traditional process } \\
\text { (TEP/year) }\end{array}$ & 3.312 & 13.219 & 1.139 & 4.880 & 6.461 & 29.013 \\
\hline $\begin{array}{l}\text { COH continuous process }(55 \% \text { moisture w.b. }) \\
\text { (t/year) }\end{array}$ & 56.464 & 225.332 & 49.149 & 210.491 & 278.721 & 820.157 \\
\hline $\begin{array}{l}\text { Energy potential COH continuous process } \\
\text { (TEP/year) }\end{array}$ & 9.091 & 36.278 & 7.913 & 33.889 & 44.874 & 132.045 \\
\hline Total $\mathrm{COH}$ availability (t/year) & 67.219 & 268.252 & 52.849 & 226.334 & 299.700 & 914.354 \\
\hline $\mathrm{COH}$ energy content (TEP/year) & 12.403 & 49.498 & 9.052 & 38.769 & 51.335 & 151.939 \\
\hline $\mathrm{EOH}(12,5 \%$ moisture $)(\mathrm{t} /$ year $)$ & 36.970 & 147.539 & 29.067 & 124.484 & 164.835 & 502.895 \\
\hline $\begin{array}{l}\text { Energy potential EOH (12,5\% moisture w.b.) } \\
\text { (TEP/year) }\end{array}$ & 13.642 & 54.442 & 10.726 & 45.935 & 60.824 & 185.568 \\
\hline
\end{tabular}

TABLE $5-\mathrm{COH}$ and $\mathrm{EOH}$ potentials in the Apulia region. 
The selling price of EOH is growing fast, in particular for district heating in the agricultural and greenhouses sector, because of the high cost of the alternative fossil fuels (diesel), and the high energy content and quality of $\mathrm{EOH}$ as biofuel.

For this reason, and in view of the aforementioned decrease of profitability in the operation of pomace oil extraction plants, which is expected to lower the $\mathrm{EOH}$ availability and increase the $\mathrm{COH}$ availability on the market in the next years, the most promising source of biofuel in the Apulia region is the $\mathrm{COH}$, in particular for the energy demand segments where biomass storage and drying facilities can be easily introduced.

\subsubsection{Biomass costs}

\section{A) Rotobaling (Scenario 1)}

The main technical and economic findings of this scenario are reported in Table 7 . The experimental test results show a working capacity of 5 bales/h (corresponding to a bale production time of 12 minutes) and about 15 bales/ha (corresponding to $6-7 \mathrm{t} / \mathrm{ha}$ ). In the PR harvesting and rotobaling cost assessment, the swath rake and the rotobaler costs are taken into account; the cost of 2 workers is also considered. The final cost of the rotobale production results of $25 € / t$; it should be stressed that the Feraboli FF50 machine used for the tests is designed for forage and straw baling and presents many operating failures when used for pruning residues. In particular, there is room for several improvements in the machine design, which could allow lowering the rotobales production costs. As an example, the intake for the biomass collection should be wider and the picker should be reinforced. Moreover, in order to avoid the brushwood to engulf the machine, getting stuck between the chain links, the conveying-winding system should be a roll system and not a chain system. With such changes, the machine could also be used for vine-shoots and other pruning residues baling.

Loading and transport costs are estimated of about $15 € / \mathrm{t}$ within a collection radius of $50 \mathrm{~km}$, thus obtaining a final rotobale cost at the conversion plant of $40 € / \mathrm{t}$. In order to optimize such costs, it is very important to implement efficient and effective collection systems, which could be managed by local contractors or directly by energy conversion plant operators.

Despite of the test results, personal communication with operators in the Apulia region report olive PR rotobales selling prices in the range of $25-30 € / t$ at the conversion plant, about $15 € / \mathrm{t}$ lower than the values from the experimental test. This difference could be due, at some extent, to the fact that the PR discharge costs are not considered in the costs assessment, while quite often these residues have to be discharged thus incurring in costs for the farmer. This could allow a further income for the biomass recovery operator, which could be estimated in the range of 70-130 €/ha. B) Picking-chipping-loading machine (Scenario 2)

The main technical and economic findings of this scenario are reported in Table 8 . In this case, the biomass should be partially dried on field before chipping. In fact, wood chips risk fermentation and quick degradation if the moisture content of the biomass is above $30 \%$. Moreover, on field chipping is a less efficient process in comparison to chipping at the storage plant by means of a stationary machine (which is the case of rotobale chipping at the power plant). The experimental test results report a working capacity of $1,5 \mathrm{t} / \mathrm{h}$ of PR chips. The final cost of the PR chips production results of $35 € / \mathrm{t}$.

\begin{tabular}{|c|c|}
\hline PARAMETER & VALUE \\
\hline Rotobale mass (kg) & 450 \\
\hline Working capacity (rotobales/hour) & 5 \\
\hline Rotobale moisture content (\% w.b.) & 35 \\
\hline LHV (MJ/kg d.b.) & 18 \\
\hline Harvesting and rotobaling cost $(€ / t)^{1}$ & 25 \\
\hline $\begin{array}{l}\text { Cost of rotobale chipping at the conversion } \\
\text { plant }(€ / t)\end{array}$ & 6 \\
\hline $\begin{array}{l}\text { Loading and transport cost (within } 50 \mathrm{~km} \\
\text { distance) }(€ / \mathrm{t})\end{array}$ & 14 \\
\hline $\begin{array}{l}\text { PR chips final cost }(€ / t) \text { (moisture content } \\
35 \% \text { w.b.) }\end{array}$ & 45 \\
\hline $\begin{array}{l}\text { PR chips final cost }(€ / \mathrm{MWh})^{2} \text { (moisture } \\
\text { content } 35 \% \text { w.b.) }\end{array}$ & 14,97 \\
\hline Avoided PR disposal cost $(€ / t)^{3}$ & 18 \\
\hline \multicolumn{2}{|c|}{$\begin{array}{l}\text { 1. By optimizing the process and adapting the rotobaling machine, } \\
\text { costs can be easily kept within } 20 € / \mathrm{t} \text {. } \\
\text { 2. The PR energy content results of } 10,8 \mathrm{MJ} / \mathrm{kg} \text { at moisture content of } \\
35 \% \text { w.b. } \\
3 \text {. Value obtained taking in account an avoided disposal cost of } \\
\text { approximately } 70-130 € / \mathrm{ha} \text {. }\end{array}$} \\
\hline
\end{tabular}

TABLE 7 - Main technical and economic parameters of the PR rotobaling scenario.

Loading and transport costs are estimated in about $15 € / \mathrm{t}$ within a collection radius of $50 \mathrm{~km}$, thus obtaining a final chip cost at the conversion plant of 50 $€ / \mathrm{t}$ and $15,2 € / \mathrm{MWh}$.

The higher biomass cost, the storage issues and the less efficient loading and transport system on respect to the rotobale scenario makes the on field chipping scenario less promising in the proposed test conditions (secular olive grove, no slope). However, the choice between the two technologies depends on several factors, such as: the land morphology, the spacing and typology of trees, the dispersion of the resource on the territory and the reliability of machinery, so that further investigations should be carried out in different test conditions.

\section{C) Olive husk market assessment}

The analysis of the geographic distribution of pomace-oil extraction plants currently in operation and plants which use EOH for power generation reports that pomace-oil extraction plants are only located in three of the five Apulian provinces (Bari, Brindisi and Lecce). The larger plants, having a working capacity 


\begin{tabular}{|c|c|}
\hline PARAMETER & VALUE \\
\hline Wood chips moisture content (\% w.b.) & 30 \\
\hline LHV (MJ/kg d.b.) & 18 \\
\hline Windrowing, harvesting and chipping cost $(€ / t)$ & 37 \\
\hline $\begin{array}{l}\text { Loading and transport cost (within } 50 \mathrm{~km} \\
\text { distance) }(€ / \mathrm{t})\end{array}$ & 18 \\
\hline $\begin{array}{l}\text { PR chips final cost (€/t) (moisture content } 35 \% \\
\text { w.b.) }\end{array}$ & 55 \\
\hline $\begin{array}{l}\text { PR chips final cost }(€ / M W h)^{1} \text { (moisture content } \\
35 \% \text { w.b.) }\end{array}$ & 16,72 \\
\hline Disposal avoided cost $(€ / t)^{2}$ & 18 \\
\hline \multicolumn{2}{|c|}{$\begin{array}{l}\text { 1. The PR energy content results of } 10,8 \mathrm{MJ} / \mathrm{kg} \text { at moisture content of } \\
35 \% \text { w.b. } \\
\text { 2. Value obtained by considering a disposal avoided cost of } 50-130 \\
€ / \text { ha. }\end{array}$} \\
\hline
\end{tabular}

TABLE 8 - Main technical and economic parameters of the $\mathrm{PR}$ on site chipping scenario.

in the range of $500-600 \mathrm{t} /$ day of $\mathrm{COH}$, are concentrated in the north of Bari. The pomace-oil plant located in Maglie (LE), having a working capacity of about 800 t/day of $\mathrm{COH}$, is integrated with a $8 \mathrm{MWe}$ power plant fired by EOH (partially produced by the local extraction plant), other biomass (wood chips, animal wheat) and RDF. The same integration of pomace-oil plant and a $10 \mathrm{MW}$ biomass power plant results in Monopoli (BA). It is also fired by wood chips, PR and other lignocellulosic biomass. The plant located in Fasano (BR) is fed by wood chips, PR and $\mathrm{EOH}$, and it produces thermal energy needed for the lime production process.

The results of the investigation on the pomace-oil sector in Apulia report a total $\mathrm{COH}$ consumption of about $300.000 \mathrm{t} / \mathrm{year}$, which is about $1 / 3$ of the total regional $\mathrm{COH}$ potentials, as reported in Table 5. The remaining quantity of $\mathrm{COH}$ (about $600.000 \mathrm{t} / \mathrm{year}$ ) is, at lesser extent, used in pomace-oil plants outside the region (even if logistic issues are the main constraints for this scenario) or for compost production; most of $\mathrm{COH}$, and in particular that one with high moisture content (mainly from continuous extraction processes) and already de-stoned at the olive oil mills, which has very low interest for pomace oil plants, is frequently discharged on agricultural field after storage in open-air ponds. For this reason, it appears clear that there is a relevant potential availability of $\mathrm{COH}$ for energy purposes in the Apulia region, which could be fully deployed if the drying and storage issues would be properly addressed. In fact, $\mathrm{COH}$ with high moisture content requires a proper drying before storage and energy conversion, which is an energy intensive process. As from the structured interviews results reported in Table 9, the average $\mathrm{EOH}$ production of the interviewed pomace-oil extraction plants in Apulia is about $120.000 \mathrm{t} / \mathrm{year}, 30 \%$ of which is consumed on site for the pomace oil extraction process. It is to be noticed that this amount of produced $\mathrm{EOH}$ is about one third of the potentials of Table 6 . Table 10 summarizes the main technical and economic parameters of olive husk and exhausted olive husk.

The results of the investigation on the pomace-oil sector show that, during the last decade, the number of pomace-oil extraction plants in operation in Apulia decreased from about 20 to 8 plants currently in operation, with the perspective of a further reduction. The reasons of this reduction are the low profitability of

\begin{tabular}{|c|c|c|c|c|c|c|c|c|c|c|}
\hline \multicolumn{3}{|c|}{ POMACE-OIL EXTRACTION PLANT } & 1 & 2 & 3 & 4 & 5 & 6 & 7 & 8 \\
\hline \multicolumn{3}{|l|}{ Province } & $\mathrm{BA}$ & $\mathrm{BA}$ & $\mathrm{BA}$ & BA & $\mathrm{BR}$ & $\mathrm{BR}$ & $\mathrm{BR}$ & LE \\
\hline \multirow{2}{*}{\multicolumn{2}{|c|}{$\mathrm{COH}$ (kt/year) }} & Min & 30 & 40 & 50 & 12 & 10 & 35 & 28 & 25 \\
\hline & & Max & 40 & 50 & 60 & 30 & 12 & 40 & 35 & 80 \\
\hline \multirow{2}{*}{\multicolumn{2}{|c|}{ Pomace oil (kt/year) }} & Min & 1,5 & 1,8 & 2 & n.a. & 0,25 & 1,75 & 0,78 & 0,75 \\
\hline & & Max & 2 & 2,25 & 2,4 & n.a. & 0,4 & 2 & 1,23 & 2,4 \\
\hline \multirow{8}{*}{ EOH (kt/year) } & \multirow{2}{*}{ Total } & Min & 16,5 & 22 & 24 & n.a. & 4,5 & 17,5 & 10,6 & 11 \\
\hline & & Max & 22 & 27,5 & 28 & n.a. & 5,4 & 20 & 13,3 & 36 \\
\hline & \multirow{2}{*}{ Available } & Min & 11,5 & 14 & 15 & n.a. & 3 & 14 & 7,3 & 8 \\
\hline & & Max & 15,4 & 17,5 & 18 & n.a. & 3,4 & 16 & 9,1 & 16,4 \\
\hline & \multirow{2}{*}{ Internal consumption } & Min & 5 & 8 & 6 & n.a. & 1,5 & 3,5 & 3,3 & 3 \\
\hline & & Max & 6,6 & 10 & 10 & n.a. & 2 & 4 & 4,2 & 9,6 \\
\hline & \multirow{2}{*}{ Olive stones } & Min & n.d. & 0 & 0 & 0 & 1,3 & 0 & 0 & 7,5 \\
\hline & & Max & n.d. & 0 & 0 & 0 & 1,6 & 0 & 0 & 24 \\
\hline \multicolumn{3}{|l|}{$\mathrm{COH}$ processed (t/day) } & 450 & 600 & n.a. & n.a. & 150 & 650 & 400 & 800 \\
\hline \multirow{2}{*}{ Purchase price $(€ / t)$} & \multirow{2}{*}{$\mathrm{COH}$} & $\mathrm{C}^{(1)}$ & 22 & 15 & n.a. & n.a. & n.a. & 10 & 12 & 15 \\
\hline & & $\mathrm{T}^{(2)}$ & 30 & 30 & n.a. & n.a. & n.a. & n.d. & 16 & 20 \\
\hline \multirow{3}{*}{ Selling price $(€ / t)$} & \multicolumn{2}{|l|}{$\mathrm{EOH}$} & 70 & 70 & n.a. & n.a. & n.a. & $70-80$ & 60 & $70-100$ \\
\hline & \multicolumn{2}{|l|}{ Husk oil } & 1500 & 1000 & n.a. & n.a. & n.a & 880 & $750-1100$ & 1000 \\
\hline & \multicolumn{2}{|l|}{ Olive stones } & 120 & - & - & - & n.a. & - & - & 70 \\
\hline
\end{tabular}

1. $\mathrm{C}=$ from continuous processes $; 2 . \mathrm{T}=$ from traditional oil mills; $\mathrm{n} . \mathrm{a} .=$ not available.

TABLE 9 - Results of the structured interviews with pomace-oil plants operators in Apulia. 


\begin{tabular}{|c|c|}
\hline PARAMETER & VALUE \\
\hline LHV of COH (MJ/kg d.b.) & 18,8 \\
\hline $\begin{array}{l}\text { Energy content of } \mathrm{COH} \text { - traditional process } \\
(\mathrm{MJ} / \mathrm{kg})\end{array}$ & 12,9 \\
\hline $\begin{array}{l}\text { Energy content of } \mathrm{COH} \text { - three-phases process } \\
(\mathrm{MJl} / \mathrm{kg})\end{array}$ & 6,7 \\
\hline Energy content of EOH (MJl/kg) & 15,4 \\
\hline Specific cost of $\mathrm{COH}$ - traditional process & $\begin{array}{c}30 € / \mathrm{t}-8,4 \\
€ / \mathrm{MWh}\end{array}$ \\
\hline Specific cost of $\mathrm{COH}$ - three-phases process & $\begin{array}{l}15 € / \mathrm{t}-8,0 \\
€ / \mathrm{MWh}\end{array}$ \\
\hline Specific cost of EOH & $\begin{array}{l}70 € / \mathrm{t}-16,3 \\
€ / \mathrm{MWh}\end{array}$ \\
\hline $\begin{array}{l}\text { Average cost of transport within } 50 \mathrm{~km} \text { distance } \\
(€ / \mathrm{t})\end{array}$ & $10-15$ \\
\hline
\end{tabular}

TABLE 10 - Main technical and economic parameters of $\mathrm{COH}$ and $\mathrm{EOH}$.

pomace oil sales, because of the strong competition of other Countries (Spain, Greece, Tunisia, Morocco, Algeria) or other Southern Italy regions (Calabria in particular) and the stringent legislative issues on atmospheric pollution and odour emissions. In particular, the lower production costs of oils in other Mediterranean Countries, mainly Spain, are due to the lower legislative issues concerning the environmental pollution, workers safety and employment contracts. Moreover, the Spanish olive oil producers, by means of efficient and effective cooperative associations, were able to reach an optimum trade off between products quality and production costs. This low profitability situation could be mitigated, at some extent, improving the efficiency of the whole regional olive-sector, by means of efficient cooperative structures which could group the operators, thus reducing the production costs and allowing an easier energy valorisation of the olive husks.

\section{Conclusions}

The objective of the proposed research was to estimate the energy potentials of the olive trees pruning residues and olive husk residues in the Apulia region (Southern Italy), and to compare the possible bioenergy conversion routes for heat and power generation.

The assessment of the technical and economic potentials in the Apulia region was carried out through a review of existing literature, structured interviews with operators, elaboration of available statistical data, assessment of the typology and current use of the by-products, analysis of olive tree pruning techniques and olive milling processes. The results report a potential of about 177.000 t/yr of PR (15\% w.b.), mainly distributed in the Provinces of Bari and Lecce, and of about 915.000 t/yr of $\mathrm{COH}$ (55\% w.b.), mainly concentrated in Bari and Lecce Provinces. The PR har- vesting and transport costs resulted in the range of 45$50 € / \mathrm{t}$ at the energy conversion plant, while the $\mathrm{COH}$ and $\mathrm{EOH}$ supply costs resulted in the range of 15-30 and $65-75 € / t$, respectively.

The analysis of the supplying methods of PR has shown that the most relevant barriers to their energy conversion are the dispersion of the resource on the territory and the lack of an adequate level of organization of the operators, which is required in order to introduce effective mechanization systems and reduce biomass supply costs.

As regards the potentials of olive husk, the results of the structured interviews report that the amount of $\mathrm{COH}$ withdrawn by pomace-oil extraction plants is about one third of the $\mathrm{COH}$ which results from the oil extraction process in the region. Moreover, the structured interviews with the main operators reported that the selling price of $\mathrm{EOH}$ is growing fast, in particular for district heating in the agricultural and greenhouses sector, because of the high cost of the alternative fossil fuels (diesel) and the high energy content and quality of EOH as biofuel. In addition, the decrease in profitability of the operation of pomace oil extraction plants, caused by several economic and environmental factors, is expected to lower the $\mathrm{EOH}$ availability and increase the $\mathrm{COH}$ availability on the market in the next years. For these reasons, the most promising source of biofuel in Apulia is $\mathrm{COH}$, in particular for the energy demand segments where biomass storage and drying facilities can be easily introduced.

\section{References}

ANPA, I rifiuti del comparto agroalimentare. Rapporti 11/2001, (2001) Available at http://www.apat.gov.it/site/ _contentfiles/00038200/38230_Rapporti_01_11.pdf.

Alburquerque J.A., Gonzalvez J., Garcia D., Cegarra J., Agrochemical characterisation of "alperujo", a solid by-product of the two-phase centrifugation method for olive oil extraction, Bioresource Technology (2004) 91, 195-200.

Alfano G. et al., Pile composting of two-phase centrifuged olive husk residues: technical solutions and quality of cured compost, Bioresour. Technol. (2007), doi:10.1016/ j.biortech.2007.09.080.

A.I.G.R. (Associazione Italiana di Genio Rurale), Potenzialità energetica da biomasse nelle regioni italiane Rapporto conclusivo - INTRODUZIONE e PARTE PRI$M A,(1994)$ Contratto A.I.G.R. - ENEA del 03 dicembre 1992 - Pratica 00073, aprile 1994.

AlKhaMis T.M., Kablan M.M., Olive cake as an energy source and catalyst for oil shale production of energy and its impact on the environment, Energy Conversion \& Management (1999) 40, 1863-1870.

Amirante P., PiPITONe F., Utilizzazione dei sottoprodotti della filiera olivicolo-olearia, OLIVAE (2002) 93, 27-32.

Amirante P., Mongelli C., Prove sperimentali di trattamento delle acque reflue di un oleificio con un impianto di incenerimento, La rivista italiana delle sostanze grasse, giugno 1992. 
Ammar E., NASri M., Medhioub K., Isolation of Enterobacteria able to degrade simple aromatic compounds from the wastewater from olive oil extraction, World Journal of Microbiology \& Biotechnology (2005) 21: 253-259.

ARrivo A., Di CANDIA E., Sottoprodotti e residui delle colture in Puglia: possibilità di meccanizzare le operazioni di recupero e trasformazione, L'informatore agrario (1983) 31.

BALDini E., Residui di potatura e risparmio energetico, L'informatore agrario (1982) 4.

BAlsari P., Airoldi G., Raccolta, trasporto ed impiego energetico delle biomasse agricole ligno-cellulosiche, Atti del Convegno UNIF, DiSAFRi, IRL, Regione Umbria "Biomasse agricole e forestali ad uso energetico", Selva di Meana (TR), settembre 2000. (2002), Agra Editrice.

Blazquez G., Hernainz F., Calero M., Ruiz-Nunez L.F., Removal of cadmium ions with olive stones: the effect of some parameters, Process Biochemistry (2005) 40, 2649-2654.

Borja R., SAnchez E., Raposo F., Rincon B., Jimenez A.M., Martin A., A study of the natural biodegradation of two-phase olive mill solid waste during its storage in an evaporation pond, Waste Management (2006) 26, 477-486.

BoubaKer F., CheIKh RHIDA B., Anaerobic co-digestion of olive mill wastewater with olive mill solid waste in a tubular digester at mesophilic temperature, Bioresource Technology (2007) 98, 769-774.

Caputo A.C., Scacchia F., Pelagagge P.M., Disposal of by-products in olive oil industry: waste-to-energy solutions, Applied Thermal Engineering (2003) 23, 197-214.

Castellano S., Candura A., Analisi territoriale per l'utilizzo sostenibile in agricoltura dei reflui oleari, Atti del Convegno AIIA 2005 "L'ingegneria agraria per lo sviluppo sostenibile dell'area mediterranea". Catania, 27-30 giugno 2005.

CElma A.R., Rojas S., LoPez-Rodriguez F., Industrial sludge processing for power purposes, Applied Thermal Engineering (2008) 28, 745-753.

CESTAAT, Impiego dei sottoprodotti agricoli e agro industriali. Volume 1, Centro Studi sull'Agricoltura l'Ambiente e il Territorio (1988), pp. 311.

Cliffe K.R., PatumSaWAd S., Co-combustion of waste from olive oil production with coal in a fluidised bed, Waste Management (2000) 21, 49-53.

Filidei S., Masciandaro G., Ceccanti B., Anaerobic digestion of olive mill effluents: evaluation of wastewater organic load and phytotoxicity reduction, Water, Air, \& Soil Pollution (2003) 145, 79-94.

Gelegenis J., Georgakakis D., Angelidaki I., ChristoPOUlOU N., GoumenaKi M., Optimization of biogas production from olive-oil mill wastewater, by codigesting with diluted poultry-manure, Applied Energy (2007) 84, 646-663.

GonZalez J.F., Gonzalez-Garcia C.M., RAMiro A., Gonzalez J., Sabio E., Ganan J., Rodriguez M.A., Combustion optimisation of biomass residue pellets for domestic heating with a mural boiler, Biomass Bioenergy (2004) 27, 145-154.

Gurbuz S., Kiran-Ciliz N., Yenigum O., Cleaner produc- tion implementation through process modifications for selected SMEs in Turkish olive oil production, Journal of Cleaner Production (2004) 12, 613-621.

ISMEA, Filiera olio di oliva, (2003) Istituto di servizi per il mercato agricolo alimentare, Roma, Italy, pp. 224.

ISTAT (2000a), $5^{\circ}$ Censimento generale dell'agricoltura.

ISTAT (2000b), Dati congiunturali sulle coltivazioni - Periodo di riferimento: anno 2000.

JARBOUI R. et al., Olive mill wastewater stabilization in open-air ponds: Impact on clay-sandy soil, Bioresource Technology (2008), doi:10.1016/j.biortech.2008.01.074.

JiMENEZ B., CARMONA C. et al., The olive tree as an energy source in the Mediterranean area: Andalusia, Proceedings of the twelfth biomass conference, Amsterdam, 1721 June 2002.

Pellerano A., Pantaleo A., Tenerelli P., Carone M.T., Studio per la valorizzazione energetica di biomasse agroforestali nella Regione Puglia, ISBN 978-8889010-06-8, pp. 207, (2007) Dipartimento PROGESA, Università di Bari.

Quaratino D., D'annibale A., Federici F., Cereti C.F., Rossini F., Fenice M., Enzyme and fungal treatments and a combination thereof reduce olive mill wastewater phytotoxicity on Zea mays L. seeds. Chemosphere (2007) 66, 1627-1633.

Raposo F., Borja R., SAnchez E., Martin M.A., Martin A., Performance and kinetic evaluation of the anaerobic digestion of two-phase olive mill effluents in reactors with suspended and immobilized biomass, Water Research (2004) 38, 2017-2026.

RODRíGUEZ G. et al., Olive stone an attractive source of bioactive and valuable compounds, Bioresour. Technol. (2007), doi:10.1016/j.biortech.2007.11.027.

Regione Puglia, Studio per l'elaborazione del Piano Energetico Regionale - Aggiornamento, (2003).

SPINElli R., SPINElli R., Prove di imballatura delle potature di olivo, L'informatore agrario (2000) 4.

SPINELLI R., L'imballatura dei residui legnosi agroforestali, L'informatore agrario (1998) 46.

Tomati U., Programma nazionale di ricerca sui reflui del sistema agricolo-industriale, sottoprogetto reflui oleari. Stato dell'arte sul problema dell'utilizzazione dei reflui oleari, (2001) Available at http://users.unimi.it/ fsangio/cnr/reflui.html.

UNAPROL, Filiera olivicola. Analisi strutturale e monitoraggio di un campione di imprese. Campagna 2004/2005, (2005), Campagna finanziata con il contributo della Comunità europea Reg. (CE) n. 1331/2004.

Vlyssides A.G., Barampouti E.M.P., Mai S.Th., Physical characteristics of olive stone wooden residues: possibile bulking material for composting process, Biodegradation (2008) 19:209-214.

\section{SUMMARY}

The main objective of the proposed research is to estimate the energy potentials of the olive trees pruning residues and olive husk residues in the Apulia region (Southern Italy) and to compare the possible bioenergy conversion routes for heat and power generation. 
The part I of the research proposes a preliminary review of the olive oil chain residues in the Apulia region and an assessment of technical potentials and biomass supply costs. The investigation is carried out through a review of existing literature, structured interviews with operators, elaboration of available statistical data, assessment of the typology and current use of the by-products, analysis of olive trees pruning techniques and olive milling processes. The results show a high potential of pruning residues (about 177 $\mathrm{kt} /$ year at $15 \%$ moisture content) and crude olive husk (about $915 \mathrm{kt} /$ year at $50 \%$ average moisture content). The supply costs are, in most cases, compatible with the energy conversion routes, and in particular they result in the range of $45-55 € / \mathrm{t}$ (35\% moisture content) for rotobales and chips from PR.

Keywords: olive husk, pruning residues, biomass potentials, biomass costs. 
